\title{
Kekuatan Otot Perut, Daya Ledak Otot Lengan, Tinggi Lompatan dan Hasil Pukulan Smash Penuh pada Atlet Bulutangkis
}

\author{
Christie Brenda Gabriella Koloway ${ }^{1}$, Joshua Runtuwene ${ }^{2}$, Fima Lanra Fredrik \\ Gerald Langi ${ }^{3}$
}

\author{
${ }^{1}$ Program Studi Ilmu Kesehatan Masyarakat Program PascasarjanaUniversitas \\ Sam Ratulangi \\ ${ }^{2}$ Fakultas Kedokteran Universitas Sam Ratulangi \\ ${ }^{3}$ Fakultas Kesehatan Masyarakat Universitas Sam Ratulangi \\ *E-mail add: bkoloway@gmail.com
}

\begin{abstract}
Abstrak
Latar Belakang: Bulutangkis ialah salah satu olahraga terpopuler dibelahan dunia termasuk di Indonesia. Olahraga bulutangkis mulai ada sejak tahun 1930-an .Kekuatan otot perut memberikan kontribusi dalam melakukan smash penuh yaitu pada saat memukul.Daya ledak merupakan satu kemampuan biometrik yang penting dalam kegiatan olahraga, karena daya ledak akan menentukan seberapa keras orang dapat memukul, menendang, melompat, berlari dan sebagainya. Tinggi lompatan merupakan komponen kesegaran jasmani untuk mengukur power otot tungkai. Tujuan penelitian ini ialah untuk menganalisis hubungan antara kekuatan otot perut, daya ledak otot lengan, tinggi lompatan dengan hasil pukulan smash penuh pada atlet bulutangkis. Metode: Penelitian ini merupakan penelitian korelasional dengan rancangan potong lintang. Penelitian ini dilakukan di Lapangan Bulutangkis SMK N 2 Manado pada bulan November 2020. Populasi ialah seluruh atlet PB se-kota manado. Instrumen penelitian yang digunakan yaitu untuk kekuatan otot perut (sit-up), untuk daya ledak otot lengan (two hand medicine ball put test), untuk tinggi lompatan (vertical jump test), hasil pukulan smash. Analisa data menggunakan dua tahap yaitu univariat dan bivariat. Hasi : Hasil analisis univariat menunjukkan bahwa responden terdistribusi paling banyak berjenis kelamin laki-laki (62\%). Selain itu diperoleh nilai rata-rata kekuatan otot perut sebesar 25,72, nilai rata-rata daya ledak otot lengan sebesar 1,52, nilai rata-rata tinggi lompatan sebesar 2, dan nilai rata-rata hasil pukulan smash sebesar 16,44. Hasil analisis bivariat menunjukkan tidak adanya hubungan antara kekuatan otot perut ( $\left.r_{\text {hitung }}=0,211<r_{\text {tabel }}=0,273\right)$, daya ledak otot lengan $\left(r_{\text {hitung }}=0,020<\right.$ $\left.r_{\text {tabel }}=0,273\right)$, dan tinggi lompatan ( $\left.r_{\text {hitung }}=-0,008<r_{\text {tabel }}=0,273\right)$ dengan hasil pukulan smash . Kesimpulan: Kesimpulan dari penelitian ini yaitu tidak ada hubungan antara kekuatan otot perut, daya ledak otot lengan, dan tinggi lompatan dengan hasil pukulan smash.

Kata Kunci: kekuatan otot perut; daya ledak otot lengan; tinggi lompatan; pukulan smash
\end{abstract}

\section{Abstract}

Background: Badminton is one of the most popular sports in the world, including in Indonesia. Badminton has been around since the 1930s. The strength of the abdominal muscles contributes 
to a full smash during hitting. Explosive power is an important biometric ability in sports activities, because the explosive power will determine how hard people can hit, kick, jump, run and so on. Jump height is a component of physical fitness to measure leg muscle power. The purpose of this study was to analyze the correlation between abdominal muscle strength, arm muscle explosive power, jump height and the result of a full smash in badminton athletes. Methods: This is a correlational research with cross-sectional approach. This research in the Badminton Field of SMK N 2 Manado in November 2020, using an analytical method with a cross-sectional design. The population is all PB athletes in Manado. The research instrument used was for abdominal muscle strength (sit-ups), for the explosive power of the arm muscles (two hand medicine ball put test), for the height of the jump (vertical jump test), the results of the smash. Data analysis used two stages, namely univariate and bivariate. Results: The results showed that the most distributed respondents based on male sex (62\%), the average value of abdominal muscle strength (25.72), the average value of arm muscle explosive power (1.52), the average value - the average jump height (2), and the average value of the smash results (16.44). The results of bivariate analysis showed that there was no relationship between abdominal muscle strength $\left(r_{\text {count }}=0.211<r_{\text {table }}=0.273\right)$, arm muscle explosive power $\left(r_{\text {count }}=0.020\right)<r_{\text {table }}=$ $0.273)$, and jump height $\left(r_{\text {count }}=-0.008<r_{\text {table }}=0.273\right)$ with a smash hit. Conclusion: That can be conclude there is no correlation between abdominal muscle strength, arm muscle explosive power, and jump height with the results of smash hits.

Keywords: Abdominal muscle strength; explosive power; jump height; smash

\section{PENDAHULUAN}

Bulutangkis ialah salah satu olahraga terpopuler dibelahan dunia termasuk di Indonesia. Olahraga bulutangkis mulai ada sejak tahun 1930-an. Ikatan Sport Indonesia (ISI) yang berjasa menaungi bulutangkis pada masa itu. Bulutangkis pun semakin berkembang pada masa setelah kemerdekaan Indonesia. Pada tahun 1947, terbentuklah Persatuan Olahraga Republik Indonesia (PORI). Menurut Aksan (2012) bulutangkis merupakan olahraga raket yang dimainkan oleh dua orang (untuk tunggal) atau dua pasangan (untuk ganda) yang mengambil posisi berlawanan di bidang lapangan yang dibagi dua oleh sebuah net (jaring).

Kunci dari keberhasilan dalam permainan tersebut adanya pukulan cepat, kuat dan terukur serta gerakan kaki yang lincah terhadap shuttlecock yang arah gerakannya selalu berubah-ubah sehingga pemain harus mampu bergerak dengan lincah untuk dapat menyesuaikan posisi tubuh secara cepat sepanjang permainan berlangsung (Andara, 2017). Untuk menjadi seorang atlet tentunya harus menguasai teknik yang ada dalam bulutangkis. Contohnya seperti pegangan raket yang terdiri dari american grip, combination grip, forehand grip, dan backhand grip. Teknik langkah kaki (footwork), teknik dasarpukulan (stroke) yang terdiridari lop, netting, servis, drive, dropshot, backhand, dan smash (Yuliawan, 2017).

Menurut Arisman, dkk (2018) menjelaskan pukulan smash dalam bulutangkis merupakan pukulan tercepat dari olahraga raket lainnya. Karakteristik pukulan ini ialah keras, laju jalannya cock cepat menuju lantai lapangan, sehingga pukulan ini membutuhkan aspek kekuatan otot tungkai, lengan, bahu, dan kelentukan (flexibility), pergelangan tangan serta koordinasi gerak tubuh yang harmonis. Menurut Rinaldi (2020), smash merupakan pukulan overhead (diatas kepala) dengan tujuan mengarahkan kok menukik tajam ke daerah lawan untuk dilakukan dengan kekuatan penuh, dan harus melatih kekuatan pada otot tungkai, bahu, lengan, dan fleksibilitas pergelangan tangan. Daya ledak otot merupakan satu kemampuan otot dalam satu kali kontraksi maksimal yang sangat cepat, dengan suatu tahanan (beban) tertentu. Semakin besar power yang 
dimiliki seorang atlit maka akan semakin baik pukulan smash yang dihasilkan (Kridasuwarso dan Hakim 2014)

Daya ledak otot sangat penting dalam hampir semua cabang olahraga terlebih khusus dalam cabang olahraga bulutangis. Asnaldi et al (2019) menjelaskan daya ledak otot lengan ialah kemampuan seseorang dalam mengarahkan kekuatan dengan cepat dalam waktu yang sangat singkat serta untuk memberikan momentum yang paling baik pada otot lengan dalam suatu gerakan yang cepat untuk melakukan aktivitas olahraga. Lengan dapat bergerak disebabkan adanya kontraksi otot. Unit dasar dari otot ialah serat otot. Beberapa serabut otot membentuk suatu unit motor yang masing-masing mempunyai kepekaan sendiri-sendiri. Otot ialah jaringan yang mempunyai kemampuan khusus yaitu berkontraksi dan dengan jalan demikian, maka suatu gerakkan akan terlaksana.

Untuk menciptakan hasil smash yang baik, perlu didukung oleh berbagai cara salah satunya dengan tinggi lompatan. Nurrohman (2010) menyatakan tinggi lompatan juga merupakan komponen kesegaran jasmani untuk mengukur power otot tungkai. Ketika melakukan tumpuan dan tolakan yang tinggi dimana pemain berusaha mendapatkan power yang maksimal, pemain tersebut akan berusaha meloncat setinggi mungkin agar dapat menghasilkan ketinggian lompat yang maksimal. Seorang pemain bulutangkis bila sedang melakukan jump smash, pemain harus melompat dengan ketinggian maksimal. Pentingnya faktor strength dan power otot tungkai dalam permainan bulutangkis, maka diperlukan metode latihan yang mampu meningkatkan strength dan power otot tungkai tersebut. Penelitian Gustaman (2019) tinggi lompatan mempunyai hubungan yang signifikan dengan pukulan smash penuh. Semakin baik tinggi lompatan maka semakin baik pula pukulan smash penuh. Peningkatan yang lebih dominan terjadi pada tinggi lompatan, dimana tinggi lompatan atau vertical jump bisa diartikan sebagai gerakan meloncat setinggi-tingginya dengan fokus kekuatan otot tungkai untuk mencapai loncatan lurus keatas dengan maksimal (Ostijic, 2010).

Penelitian ini penulis mengambil subjek pemain bulutangkis Atlet Taruna Se-Kota Manado karena di era new normal ini mereka telah mulai mengadakan latihan dengan menggunakan protokol kesehatan yang ada. Sesuai pengamatan dalam penelitian ini bahwa pebulutangkis taruna Perkumpulan Bulutangkis (PB) Se-Kota Manado mempunyai teknik dasar yang baik dari mulai cara memegang raket (grips), gerakan melangkah kaki (footwork), teknik penguasaan pukulan (strokes) dan teknik menguasai pola-pola pukulan (servis, lob, dropshort, drive dan smash) tidak semua pebulutangkis memiliki kondisi fisik yang baik, hal ini terlihat ketika pada saatlatihan teknik maupun latihan uji tanding di situasi pandemi covid-19. Masalah paling penting yang ditemukan, yaitu sebagian besar atlet belum mampu melakukan smash penuh dengan sempurna sehingga hasil smash cock meluncur lambat bahkan sering tidak melewati net. Tujuan penelitian ini yaitu untuk menganalisis hubungan antara kekuatan otot perut, daya ledak otot lengan, tinggi lompatan dengan hasil pukulan smash penuh pada atlet bulutangkis

\section{METODE PENELITIAN}

Penelitian ini merupakan penelitian korelasional dengan rancangan potong lintang. Penelitian dilakukan di SMK N 2 Manado pada bulan November 2020. Sampel diambil dari total populasi Atlet PB Se-Kota Manado yang berjumlah 50 atlet yang terdiri dari 31 atlet laki-laki, dan 19 atlet perempuan yang memenuhi kriteria inklusi yaitu terdaftar sebagai atlet taruna PB Se-Kota Manado, keadaan sehat, mampu membaca dan 
menulis, kategori usia 16-30 tahun, menandatangani lembar persetujuan sebagai subjek, dan bersedia mematuhi kriteria subjek teliti.

Variabel bebas dalam penetian ini yaitu kekuatan otot perut $\left(\mathrm{X}_{1}\right)$, daya ledak otot lengan $\left(\mathrm{X}_{2}\right)$, dan tinggi lompatan $\left(\mathrm{X}_{3}\right)$. Variabel terikat yaitu hasil pukulan smash penuh (Y). Instrumen penelitian yang digunakan yaitu melakukan tes pengukuran pada atlet. Untuk mengukur kekuatan otot perut dalam penelitian ini ialah skor yang diperoleh setelah atlet melakukan tes baring duduk/ sit-up yang benar selama 30 detik. Untuk daya ledak otot lengan ialah skor yang diperoleh atlet mendorong bola medicine yaitu bola khusus mengukur daya ledak otot lengan ke depan sejauh mungkin. Jarak tolakan bola medicine yang terjauh dari tiga kali kesempatan dicatat sebagai hasil tes atlet.Untuk tes tinggi lompatan yaitu atlet melakukan vertical jump (loncat tegak) sebanyak 3 kali diambil jarak lompatan yang tertinggi (Depdiknas, 2010). Untuk hasil pukulan smash penuh ialah skor yang diperoleh atlet melakukan pukulan smash penuh ke daerah tepi selebar $40 \mathrm{~cm}$ sebelah kanan ataupun sebelah kiri yang telah diberi skor. Setiap atlet diberi kesempatan melakukan smash penuh sebanyak 10 kali dari sebelah kiri dan kanan. Total skor yang diperoleh dari 20 kali kesempatan untuk melakukan smash penuh, merupakan skor dari atlet (Poole, 2016).

Data yang dikumpulkan dalam penelitian ini melalui tes pengukuran. Analisa data menggunakan dua tahap yaitu univariat dan bivariat. Analisis univariat menggunakan nilai minimal, maksimal, mean, dan standar deviasi. Analisis bivariat menggunakan uji pearson product moment untuk melihat ada tidaknya hubungan antara variable penelitian.

\section{HASIL DAN PEMBAHASAN}

Hasil analisis data secara univariat menjelaskan tentang hasil perhitungan deskriptif setiap variabel. Hal ini dapat dilihat pada Tabel 1.

Tabel 1. Hasil perhitungan deskriptif

\begin{tabular}{|c|c|c|c|c|c}
\hline No & Variabel & Min & Max & Mean & $\begin{array}{c}\text { Standar } \\
\text { Deviasi }\end{array}$ \\
\hline 1 & Kekuatan Otot Perut & 15 & 35 & 25,73 & 5,47 \\
\hline 2 & Daya Ledak Otot Lengan & 1,25 & 1,85 & 1,52 & 0,20 \\
\hline 3 & Tinggi Lompatan & 15 & 27 & 20 & 3 \\
\hline 4 & Hasil pukulan Smash & 12 & 20 & 16,44 & 2,34 \\
\hline
\end{tabular}

Dari Tabel 1, menunjukkan nilai statistik deskriptif dari masing-masing variabel yaitu nilai rata-rata untuk kekuatan otot perut sebesar 25,72 dan standar deviasi sebesar 5,47 dari 50 orang atlet. Nilai ini menunjukkan bahwa skor tersebut tergolong cukup baik dimana dari pengambilan sit up selama 30 detik. Dari jumlah tersebut diperoleh nilai minimum sebesar 15 dan maksimum sebesar 35. Dengan kata lain dalam 30 detik, atlet dengan jumlah sit up terendah adalah 15 kali dan tertinggi adalah 35 kali.

Nilai rata-rata daya ledak otot lengan sebesar 1,52 meter dan standar deviasi sebanyak 0, 2. Dengan kata lain hasil test pelemparan Bola medisin seberat $2,7216 \mathrm{~kg}$ (6 pounds) memiliki hasil yang mengagumkan dengan hasil yang diluar ekspektasi. Hal ini karena nilai rata-rata menunjukkan hasil lebih tinggi dari papan skala, hal ini dengan kata lain terdapat beberapa atlit yang memiliki hasil lemparan di atas 1,50 meter. Hal ini terlihat dari nilai maksimum lemparan yang dilakukan atlit sejauh 1,85 meter dan nilai minimum sebanyak 1,25 meter.

Nilai rata-rata untuk tinggi lompatan adalah 20 dengan standar deviasi sebanyak 3. Hasil ini cukup baik dimana para atlit memiliki hasil lompatan yang berada pada titik 
standar. Hal ini terlihat dari nilai minum 12 dan nilai maksimum sebanyak 27. Nilai ratarata untuk hasil pukulan smash adalah 16,44 dengan standar deviasi, sebanyak 2,34. Hal ini memiliki makna dari percobaab pukulan smash sebanyak 20 kali, para atlet berhasil meraih pukulan yang lebih dari 10 pukulan. Hal ini terlihat dari nilai minimum atlet yang mampu memukul sebanyak 12 pukulan dan atlit yang mampu memukul dengan nilai maksimal yakni 20 pukulan.

Hasil penelitian Permadi (2017) menyatakan bahwa rata-rata kekuatan otot perut pada atlet bulutangkis PB Pahlawan Sumenep sebesar 26, hal ini lebih besar dari pada rata-rata yang diteliti pada atlet bulutangkis di Manado. Hasil penelitian Lisdiantoro (2016) menyatakan bahwa rata-rata daya ledak otot lengan yaitu sebesar 8,071, hal ini juga lebih besar dari nilai pada atlet bulutangkis di Manado. Hasil penelitian Andara dan Wiriawan (2018) menyatakan bahwa rata-rata tinggi lompatan PB Satria Muda yaitu $33,60 \mathrm{~cm}$, hal ini menunjukkan bahwa lebih besar rata-rata tinggi lompatan atlet bulutangkis di Manado. Hasil penelitian Lisdiantoro (2016) juga menyatakan rata-rata kemampuan smash sebesar 17,07, hal ini lebih besar dari pada kemampuan smash atlet bulutangkis di Manado.

Selanjutnya dilakukan analisis bivariat, namun sebelum masuk ke tahap tersebut maka dilakukan uji normalitas data. Hal ini dapat dilihat pada Tabel 2.

Tabel 2. Hasil Uji Normalitas

\begin{tabular}{|c|c|c|c|c}
\hline No & Variabel & $\mathrm{N}$ & $\begin{array}{c}\text { Komogorov } \\
\text { Smirnov }\end{array}$ & Keterangan \\
\hline 1 & Kekuatan Otot Perut & 50 & 0,785 & Normal \\
\hline 2 & Daya Ledak Otot Lengan & 50 & 0,559 & Normal \\
\hline 3 & Tinggi Lompatan & 50 & 0,597 & Normal \\
\hline 4 & Hasil Pukulan Smash & 50 & 0,571 & Normal \\
\hline
\end{tabular}

Berdasarkan tabel 2, terlihat bahwa nilai signifikansi untuk variabel $\mathrm{X}_{1}$ sebesar $0,785, \mathrm{X}_{2}$ sebesar $0,559, \mathrm{X}_{3}$ sebesar 0,597 dan $\mathrm{Y}$ sebesar 0,571. Hasil tersebut memiliki hasil lebih dari 0,05. Berdasarkan nilai signifikansi tersebut dapat disimpulkan bahwa data terdistribusi normal dan bisa dilanjutkan untuk analisis bivariat menggunakan uji pearson product moment. Hasil analisis data secara bivariat menjelaskan hubungan antara variabel bebas dan terikat. Hal ini dapat dilihat pada Tabel 3

Tabel 3. Hasil Uji Analisis Bivariat

\begin{tabular}{cccc}
\hline No & Hubungan antar variabel & Nilai $\mathrm{r}$ & Nilai $\mathrm{p}$ \\
\hline 1 & $\mathrm{X} 1-\mathrm{Y}$ & 0,211 & 0,060 \\
2 & $\mathrm{X} 2-\mathrm{Y}$ & 0,020 & 0,862 \\
3 & $\mathrm{X} 3-\mathrm{Y}$ & $-0,008$ & 0,344 \\
\hline
\end{tabular}

Tabel diatas memperlihatkan bahwa rhitung dari hubungan antara X1 dengan $\mathrm{Y}$ sebesar 0,211, $\mathrm{X}_{2}$ dengan $\mathrm{Y}$ sebesar 0,020, dan $\mathrm{X}_{3}$ dengan $\mathrm{Y}$ sebesar -0,008 Berdasarkan persyaratan korelasi maka $\mathrm{r}_{\text {hitung }}$ harus lebih besar dari $\mathrm{r}_{\text {tabel }}$ dengan jumlah sampel sebanyak 50 atlet dengan signifikansi 0,05 ialah 0,273. Nilai ini menunjukkan bahwa antara kekuatan otot perut, daya ledak otot lengan, dan tinggi lompatan tidak memiliki kontribusi yang signifikan terhadap hasil pukulan smash. Hasil pengukuran juga terlihat dari nilai $\mathrm{p}$ antara $\mathrm{X}_{1}$ dengan $\mathrm{Y}$ sebesar $0,060, \mathrm{X}_{2}$ dengan $\mathrm{Y}$ sebesar $0,862, \mathrm{X}_{3}$ dengan $\mathrm{Y}$ sebesar 0,344 ( $p$-value $<0,05)$ yang berarti tidak ada hubungan yang signifikan antara kekuatan otot perut, daya ledak otot lengan, dan tinggi lompatan dengan hasil pukulan smash. 


\section{Hubungan antara kekuatan otot perut dengan hasil pukulan smash penuh}

Meningkatkan kekuatan otot fisioterapi memberikan latihan untuk membantu meningkatkan kekuatan pada individu yang mengalami kelemahan saat melakukan smash, dan latihan itu memfokuskan pada penguatan otot dari individu itu sendiri. Pukulan smash yang baik akan mendapatkan hasil yang baik jadi kekuatan otot sangat penting dalam permainan bulutangkis. Melakukan smash ada beberapa latihan yang harus di berikan agar saat pukulan smash yang di hasilkan maksimal latihan yang di berikan situp dan isotonik tricep untuk membuktikan pengaruh peningkatan kekuatan smash pada pemain bulutangkis.

Hasil $\mathrm{r}\left(\mathrm{x}_{1}, \mathrm{y}\right)=\left(\mathrm{r}_{\text {hitung }}=0,211<\mathrm{r}_{\text {tabel }}=0,273\right)$, secara kuantitatif hasil ini menyimpulkan tidak ada hubungan antara kekuatan otot perut dengan hasil pukulan smash atlet bulutangkis. Kondisi ini terlihat dari hasil test kekuatan otot perut dengan sit-up yang dilakukan Michael (responden ke-9) yang hanya mampu menghasilkan 27 kali dalam 30 detik namun berhasil memukul 20 pukulan smash. Hal ini berbeda dengan Vincent (responden ke-30) yang hanya mampu memukul 16 pukulan smash. Dua perbandingan tersebut semakin menguatkan bagaimana kekuatan otot perut tidak menjamin seorang atlet untuk mampu memukul smash dengan cukup banyak dalam dua puluh kali percobaan. Hasil penelitian ini didukung oleh penelitian Legeayem, dan Wiriawan (2017) tentang kontribusi otot lengan, otot perut, otot kaki, dan power kaki terhadap jumping smash pada bulutangkis. Penelitian ini menyatakan bahwa otot perut tidak mempunyai kontribusi yang signifikan terhadap pukulan jumping smash dapat di lihat pada Nilai $r_{\text {hitung }}$ $(0,548)<\mathrm{r}_{\text {tabel }}(0,632)$.

Hasil Penelitian ini berbeda dengan hasil penelitian Setiawan, (2020) yang menyatakan terdapat hubungan antara kekuatan otot lengan dan koordinasi mata-tangan dengan akurasi smashforehand dalam permainan bulutangkis. Kondisi ini juga berbeda dengan Setyawan (2016) yang menyatakan ada hubungan yang signifikan antara kekuatan otot lengan dan power otot tungkai dengan ketepatan smash dalam permainan bulutangkis siswa sekolah bulutangkis di Perkumpulan Bulutangkis (PB) Mataram Raya Sleman. Perbedaan hasil penelitian ini disebabkan dari faktor situasi dan kondisi atlet. Hasil penelitian tidak terdapat hubungan dikarenakan pada saat pengambilan data, atlet selama 7 bulan terakhir tidak melakukan latihan rutin karena situasi Pandemi Covid-19, sehingga kondisi fisik atlet menurun. Oleh karena itu perlu dilakukan analisis yang lebih mendalam lagi bagaimana kekuatan otot perut bisa berhubungan dengan pukulan smash penuh.

Sit-up ialah suatu jenis senam kekuatan yang berfungsi untuk menguatkan otot bisep maupun trisep. Posisi awal tidur tengkurap dengan tangan di sisi kanan kiri badan. Kemudian badan didorong ke atas dengan kekuatan tangan. Posisi kaki dan badan tetap lurus atau tegap. Setelah itu, badan diturunkan dengan tetap menjaga kondisi badan dan kaki tetap lurus. Badan turun tanpa menyentuh lantai atau tanah. Naik lagi dan dilakukan secara berulang. Push-up ialah suatu jenis senam kekuatan yang berfungsi untuk menguatkan otot bisep maupun trisep. Push-up ialah bentuk latihan yang menggunakan kekuatan otot lengan dengan beban diri sendiri. Tujuan melakukan push-up ialah untuk menguatkan kekuatan otot lengan. Latihan push-up juga bertujuan untuk memberikan kebugaran jasmani, karena memberikan aktivitas tubuh menggunakan tangan naik turun (Hasyim, dkk 2021).

\section{Hubungan antara daya ledak otot lengan dengan hasil pukulan smash penuh}

Kekuatan otot lengan merupakan daya dorong dari gerakan lanjutan lengan yang membuat hasil pukulan terhadap shuttlecock lebih kuat. Berdasarkan hal tersebut, jelas 
bahwa kekuatan otot lengan mempunyai hubungan yang erat dan mempunyai peranan yang penting dalam menunjang keberhasilan pelaksanaan smash bulutangkis. Tanpa memiliki kekuatan otot lengan yang baik, jangan mengharapkan atlet dapat melakukan smash dengan baik. Kekuatan otot lengan yang baik memberikan dampak positif berkaitan dengan penggunaan daya dalam melakukan suatu pukulan. Pemain yang memiliki kekuatan otot lengan yang lebih besar, maka akan lebih menguntungkan pada saat akan memukul shuttlecock.

Berdasarkan hasil pengukuran yang dilakukan terhadap 50 atlet bulutangkis diperolah hasil $\mathrm{r}\left(\mathrm{x}_{2}, \mathrm{y}\right)=0,020$ yang lebih kecil dengan rtabel untuk 50 orang sampel yakni 0,273 . Secara kuantitatif hasil ini menyimpulkan daya ledak otot lengan tidak memiliki hubungan dengan hasil pukulan smash atlet bulutangkis. Kondisi ini terlihat dari hasil test daya ledak otot lengan dengan tiga percobaan, secara akumulatif y dilakukan Jeremia (responden ke-16) yang mampu melempar sejauh 5,75 meter namun berhasil memukul 14 pukulan smash. Hal ini berbeda dengan Jesika (responden ke-33) yang hanya mampu melempar sejauh 4,55 meter mampu memukul dengan sempurna 20 pukulan smash. Dua perbandingan tersebut semakin menguatkan bagaimana daya ledak otot lengan tidak menjamin seorang atlet untuk mampu memukul smash dengan cukup banyak dalam dua puluh kali percobaan. Penelitian ini bahwa tidak ada hubungan antara daya ledak otot lengan dengan hasil pukulan smash pada atlet bulutangkis. Hasil penelitian ini didukung dengan penelitian yang dilakukan Irwan, dkk (2018) tentang hubungan antara daya ledak otot lengan dan kekuatan genggaman tangan dengan kemampuan smash dalam permainan bulutangkis, menyatakan bahwa daya ledak otot lengan tidak memiliki hubungan dengan kemampuan smash dapat dilihat dari Nilai $r_{\text {hitung }}=0,053<r_{\text {tabel }}=0,514$. Hasil penelitian yang dilakukan Haq (2016) juga menyatakan bahwa tidak terdapat hubungan yang signifikan antara kekuatan otot lengan dengan ketepatan jumping smashpada atlet bulutangkis Kabupaten Jombang dengan nilai hanya sebesar 5,34\%.

Berbeda dengan penelitian Hermanto (2016) yang diperoleh daya ledak otot lengan mempunyai hubungan signifikan dengan kemampuan smash pemain bulutangkis Club Cupumanik Bhayangkara Kecamatan Bangko Bagan Siapi-api, ditandai dengan hasil yang diperoleh yaitu rhitung 0,48> rtabel 0,444. Penelitian ini juga sejalan dengan Prabowo (2015) hasil analisis data diperoleh perhitungan daya ledak otot tungkai, kekuatan otot lengan, kelentukan pergelangan tangan dengan hasil smash normal diketahui $F_{\text {hitung }}$ masing-masing sebesar 18,02( $\left.\mathrm{X}_{1}\right), 34,56\left(\mathrm{X}_{2}\right)$, dan 21,88( $\left.\mathrm{X}_{3}\right)>\mathrm{F}_{\text {tabel }} 4,60$ jadi hipotesis diterima. Simpulan penelitian ini ialah terdapat hubungan daya ledak otot tungkai, kekuatan otot lengan, dan kelentukan pergelangan tangan dengan hasil smash normal pada atlet klub bola voli Putra Mustika Blora tahun 2015, atau dengan Asnaldi (2020) daya ledak otot lengan memiliki kontribusi yang berarti terhadap ketepatan smashsiswa SMKN 1 Solok-Selatan sebesar 41,22\%. Artinya ketepatan smash dapat ditingkatkan melalui daya ledak otot lengan. Perbedaan hasil penelitian ini disebabkan dari faktor situasi dan kondisi atlet. Hasil penelitian tidak terdapat hubungan dikarenakan pada saat pengambilan data, atlet selama 7 bulan terakhir tidak melakukan latihan rutin karena situasi Pandemi Covid-19, sehingga kondisi fisik atlet menurun. Oleh karena itu perlu dilakukan analisis yang lebih mendalam lagi bagaimana daya ledak otot lengan bisa berhubungan dengan pukulan smash penuh.

\section{Hubungan antara tinggi lompatan terhadap hasil pukulan smash penuh}

Seorang pemain bulutangkis bila sedang melakukan jump smash, pemain harus melompat dengan ketinggian maksimal. Pentingnya faktor strength dan power otot tungkai dalam permainan bulutangkis, maka diperlukan metode latihan yang mampu 
meningkatkan strength dan power otot tungkai tersebut. Terdapat perbedaan yang nyata (signifikan) diantara teknik loncatan vertikal dan teknik loncatan parabol depan terhadap akurasi shuttlecock. Terdapat perbedaan yang nyata (signifikan) teknik loncatan vertikal dan teknik loncatan parabol depan terhadap kecepatan shuttlecock. Dimana teknik loncatan parabol depan memiliki hasil lebih baik dari pada loncatan vertikal.

Berdasarkan hasil pengukuran yang dilakukan terhadap 50 atlet bulutangkis diperolah hasil $\mathrm{r}\left(\mathrm{x}_{3}, \mathrm{y}\right)=-0$, 008 yang lebih kecil dengan rtabel untuk 50 orang sampel yakni 0,273. Secara kuantitatif hasil ini menyimpulkan tinggi lompatan tidak ada hubungan dengan hasil pukulan smash atlet bulutangkis. Kondisi ini terlihat dari hasil test tinggi lompatan dengan tiga percobaan, secara akumulatif yang dilakukan Calvin (responden ke-1) yang mampu melompat setinggi 7,9 centimeter namun berhasil memukul 15 pukulan smash. Hal ini berbeda dengan Agus (responden ke-27) yang hanya mampu melompat setinggi 5,15 meter mampu memukul dengan sempurna 20 pukulan smash. Dua perbandingan tersebut semakin menguatkan bagaimana tinggi lompatan tidak menjamin seorang atlet untuk mampu memukul smash dengan cukup banyak dalam dua puluh kali percobaan. Penelitian ini memperlihatkan bahwa tidak ada hubungan antara tinggi lompatan dengan hasil pukulan smash pada atlet bulutangkis.

Berbeda dengan hasil penelitian yang dilakukan oleh Gustaman (2019), menyatakan bahwa terdapat hubungan yang signifikan antara tinggi lompatan dengan kemampuan smash bulutangkis, dapat dilihat dari nilai sebesar 0,85 (72,5\%). Perbedaan hasil penelitian ini disebabkan dari faktor situasi dan kondisi atlet. Hasil penelitian tidak terdapat hubungan dikarenakan pada saat pengambilan data, atlet selama 7 bulan terakhir tidak melakukan latihan rutin karena situasi Pandemi Covid-19, sehingga kondisi atlet secara fisik menurun. Oleh karena itu perlu dilakukan analisis yang lebih mendalam lagi bagaimana tinggi lompatan bisa berhubungan dengan pukulan smash penuh.

Tidak adanya pengaruh antara ketiga variabel $\mathrm{X}$ terhadap variabel $\mathrm{Y}$, bukan berarti hasil pengukuran terhadap atlet bulutangkis ini tidak dapat diterima. Dari hasil pengukuran ini, pada dasarnya terlihat bahwa 50 orang atlet yang di test sudah memiliki daya tahan tubuh yang cukup untuk menjadi atlet bulutangkis, oleh karena itu apapun hasil pengukuran dari ketiga variabel $X$ tidak akan mempengaruhi kemampuan mereka dalam melakukan smash. Ada dua faktor yang mempengaruhi hasil pukulan smash yaitu faktor internal dan faktor eksternal. Faktor internal yang mempengaruhi pukulan smash penuh atlet bulutangkis antara lain, fisik, taktik dan mental yang dimiliki atlet tersebut. Fisik yang prima pada saat pengukuran cukup menentukan atlet dalam memukul 20 smash penuh dalam satu pengukuran. Hal ini juga berlaku pada taktik yang dimiliki atlet seperti kemampuannya dalam menangkap ketepatan shuttlecock untuk jatuh dititik utama ketika melakukan smash, dan bagaimana kecepatan tangan dalam melakukan smash. Sikap mental seorang atlet juga menentukan keberhasilannya dalam melakukan smash penuh seperti ketenanganoptimistik.

Faktor eksternal juga memberikan pengaruh terhadap pukulan smash penuh atlet bulutangkis. Faktor eksternal tersebut meliputi pelatih, sarana dan prasarana, keluarga, lingkungan dan gizi. Aspek pelatih cukup mempengaruhi seperti kecakapan pelatih untuk memberikan instruksi latihan yang memadai akan membantu atlet dalam mencapai hal yang maksimal dalam latihan. Aspek sarana dan prasarana seperti gedung, latihan, peralatan lainnya juga turut membantu atlet dalam menciptakan kondisi latihan yang baik. Keluarga pada dasarnya tidak terlalu mempengaruhi hanya saja latar belakang keluarga yang mendukung sangat membantu atlet bulutangkis untuk mampu meraih hasil yang maksimal. Aspek lingkungan seperti pertemanan antar atlet juga menjadi faktor yang 
memberikan kontribusi untuk membentuk keyakinan dan rasa optimistik seorang atlet. Perasaan mendapat dukungan dari rekan sesama atlet akan mampu meningkatkan emosional yang positif bagi atlet bulutangkis. Faktor eksternal lainnya ialah gizi seorang atlet. Gizi disini termasuk asupan makanan bergizi akan menentukan kondisi fisik ideal atlet dan tentu mempengaruhi kemampuan atlet dalam melakukan pukulan smash penuh

\section{PENUTUP}

Kesimpulan dalam penelitian ini yaitu kekuatan otot perut, daya ledak otot lengan, dan tinggi lompatan tidak berhubungan dengan hasil pukulan smash penuh pada atlet bulutangkis di kota Manado. Berdasarkan penelitian ini harus dilakukan penelitian lanjutan tentang kontribusi kekuatan otot perut, daya ledak otot lengan, dan tinggi lompatan terhadap hasil pukulan smash pada sample size lebih besar.

\section{REFERENSI}

Aksan, H. 2012. Mahir Bermain Bulutangkis. Nuansa Cendikia. Bandung

Andara, E. H. 2017. Perbandingan komponen kondisi fisik bulutangkis pada atlet PB FIFA Sidoarjo dan atlet PB Satria Muda Sidoarjo U17. Jurnal Unnes. 2 (3)

Arisman, A, \& Saripin, S. 2018. Hubungan kelentukan pergelangan tangan dan power otot lengan-bahu dengan hasil akurasi smash bulutangkis putra pada PB Angkasa Pekanbaru. Journal Of Sport Education. 1(1): 9-16.

Asnaldi, A., Nirwandi, N., \& Aprisandy, D. (2019). Pengaruh weight training terhadap peningkatan daya ledak otot lengan. Sport Science, 19 (1), 1-9.

Depdiknas. 2010. Tes kesegaran jasmani indonesia untuk anak umur 16-19 tahun. Depdiknas. Jakarta.

Haq, P, F. 2016. Kontribusi Power Otot Tungkai, Kekuatan Otot Lengan, Kekuatan Otot Perut, Kekuatan Otot Peras Tangan, Dan Konsentrasi Terhadap Ketepatan Pukulan Jumping Smash Pada Atlet Bulutangkis Kabupaten Jombang. Universitas Nusantara PGRI Kediri. Artikel Skripsi.

Hasyim, N., \& Muhajir. S. 2021. Pendidikan Jasmani Olahraga dan Kesehatan. PT Elex Media Komputindo. 98 Hal

Hermanto, Bambang., Ramadi, R., Agust, K., 2016. Hubungan antara Daya Ledak Otot Lengan dan Daya Ledak Otot Tungkai dengan Kemampuan Smash Pemain Bulutangkis Club Cupumanik Bhayangkara Kecamatan Bangko Bagan Siapiapi." Jurnal Online Mahasiswa Fakultas Keguruan dan Ilmu Pendidikan Universitas Riau, vol. 3, no. 2.

Irwan, L, M., Candra, D, W., \& Muliyani, S, E. 2018. Hubungan Antara Daya Ledak Otot Lengan Dan Kekuatan Genggaman Tangan Dengan Kemampuan Smash Dalam Permainan Bulutangkis Pada Club Pb Bintang Generasi Kota Raja tahun 2018. Jurnal Undikma. 5 (2)

Ismaryati. 2011. Tesdan pengukuranolahraga. Universitas Sebelas Maret. Surakarta

Kridisuwarso, B., \& Hakim, A, A. 2014. Biomekanika Olahraga. CV Jakad Media Publishing; Surabaya. 106 Hal.

Legeayem, T, R., \& Wiriawan. 2017. Kontribusi Kekuatan Otot Lengan, Otot Perut, Otot Kaki, dan Power Kaki Terhadap Jumping Smash Pada Bulutangkis. Jurnal Ilmu Keolahragaan. 20 (1)

Lisdiantoro, G. 2016. Hubungan Antara Koordinasi Mata Tangan, Power Otot Lengan dan Kekuatan Otot Perut Dengan Kemampuan Pukulan Smash Dalam Permainan Bulutangkis. Premiere Educandum. Volume 6 Nomor 2. 
Ostojić. S.M., Stojanović M., Ahmetović Z. 2010. Vertical jump as a tool in assessment of muscular power and anaerobic performance. Med Pregl. 63(5-6):371-5.

Permadi, G, A., 2017. Survey Tingkat Kondisi Fisik Atlet Bulutangkis PB. Pahlawan Sumenep. Jurnal Ilmiah Mandala Education. Vol. 3, No. 2.

Poole, J. 2016. Belajar bulutangkis. CV. Pioner Jaya. Bandung.

Prabowo, D, A. 2015.Hubungan daya ledak otot tungkai kekuatan otot lengan dan kelentukan pergelangan tangan dengan hasil smash normal. Universitas Negeri Semarang. Tesis

Rinaldi, M. 2020. Buku Jago Bulutangkis. Cemerlang; Tangerang Selatan 100 Hal.

Setiawan, A. 2020. Akurasi smashforehand bulutangkis dikaitkan dengan kekuatan otot lengan dan koordinasi mata-tangan. Jurnal Unsur. Volume 10 Nomor 1 Edisi Juni 2020.

Setyawan, I. 2016. Hubungan Antara Kekuatan Otot Lengan dan Power Otot Tungkai dengan Ketepatan Smash dalam Permainan Bulutangkis Siswa Sekolah Bulutangkis Mataram Raya Sleman Tahun 2016. Pendidikan Jasmani Kesehatan dan Rekreasi. Vol 5, No 8.

Surahman, F., Yeni, H, O., \& Sanusi, R. 2019. Hubungan Daya Ledak Otot Lengan Dan Kelentukan Pinggang Dengan Kemampuan Smash Bulutangkis Pada Ekstrakurikuler Siswa Sma N 2 Karimun. Jurnal Pendidikan MINDA. Vol. 1, No. 1

Yuliawan, D. 2017. Bulutangkis dasar. Yogyakarta: CV Budi Utama. 